\title{
Introduction: Gasparo Contarini and Enduring Institutions
}

\author{
FILIPPO SABETTI
}

Gasparo Contarini was a Venetian gentleman born in 1483 who died a prince of the church in Bologna in 1542. He belonged to an old Venetian family and had a distinguished career, first as a patrician and then as a prelate. Since the 1950 s, a succession of specialized monographs on Renaissance history and the discovery of archival material have added much knowledge about Contarini's social, intellectual, and spiritual journey as a young man and his emergence and presence on the stage of public and ecclesiastical life. The various phases of Contarini's life were brought together in the early 1990s in a biography (Gleason 1993). Since then, additional research - largely undertaken at the Ca' Foscari University of Venice - has amplified our knowledge of Contarini as a diplomat and writer (e.g., Florio 2009; Negrato 2012). Yet he is best remembered for his reflections on the government of the Republic of Venice that he penned, and circulated among his friends, between 1522 and 1525 and then again between 1533 and 1534 (e.g., Bowd 1998, 174-5). These reflections were posthumously published as De magistratibus et republica Venetorum in Paris in 1543. This book presents the first modern English-language edition of Contarini's work to be translated from the original Latin.

Contarini was the eldest of seven sons and two daughters of Alvise Contarini and Polissena Malpiero. His life has been generally broken down into four periods: his education up to 1509; his years as a scholar and member of the Great Council between 1508 and 1518; his service to the Venetian republic, 1518-35; and his career as a churchman, 1535-42 (e.g., Bowd 1998; Donnelly 2002, 9; Fragnito 1988; Gilbert 1967, 1968, 1969; Jedin 1958; Matheson 1972; Ross 1970, 1972). As a young man, Contarini took seriously the challenge of deciding which path to follow: the contemplative life, like some of his close friends who entered the cloister, or the active life of a patrician gentleman. The decision came, 
as he recounted, by chance and from an unexpected source: a monk, hearing his confession on Holy Thursday in 1511, made him realize that it was possible to live in the presence of Christ in the secular world, and to achieve human happiness and salvation in the midst of the city (Bowd 1998, 52-63; Fragnito 1969, 101-4; Gleason 1993, 14-15).

Contarini accepted a strong union of faith and reason and drew on St Thomas to assert the capacity of human beings to understand the world around them through the use of their faculties, properly exercised. He acknowledged that original sin and nature set limits to human knowledge without, however, denying the human striving to use reason as much as possible (Gleason 1993, 84-5). At the same time, he recognized that not all questions about the meaning of human life and destiny could be answered by philosophical enquiry. Revelation, tradition, and faith provided satisfactory answers where and when philosophy could not. Thus Contarini combined, to put matters in modern terms (Savorana 2017, 998), the pessimism that Christians associate with the nature of man and the optimism about human affairs that they derive from the incarnation of Christ. Human action is fallible but capable of instruction and certainly is not predetermined by original sin. Against this backdrop, it comes as no surprise that Contarini, while in public life and before becoming a priest and cardinal, initially wrote about theological and religious matters (Fragnito 1969; Gleason 1993, 83).

As a member of one of Venice's most distinguished families, Contarini had the necessary pedigree for an active role in the governance of the Republic. ${ }^{1}$ In 1508 he entered the Great Council, the sovereign assembly of the Republic consisting of all patricians over twenty-five years of age. He served initially in various junior capacities, including as state attorney and surveyor of reclaimed land. Between 1520 and 1525, he was the Venetian ambassador to the court of the Holy Roman Emperor Charles $\mathrm{V}$, and was present at the signing of the Peace of Bologna in 1530. In over four hundred dispatches ${ }^{2}$ he reported, with the aid of two secretaries, on

1 Elisabeth Gleason $(1993,2)$ recalls that the Contarini clan gave the Republic eight doges, the first of whom helped to start the construction of St Mark's Basilica in the eleventh century. By the time of Gasparo's birth, three of his ancestors had been elected doge (and another five would hold that post after his death). The Dizionario biografico degli Italiani has entries on more than seventy Venetian Contarini, and that on Gasparo by Gigliola Fragnito (1983) is the longest, covering twenty pages. See Appendix C listing the principal events of Contarini's life.

2 For useful guides on how to read Contarini's diplomatic dispatches, see de Vivo 2011, Halikowski Smith 2017, and Negrato 2012. Halikowski Smith also maps Contarini's travels throughout Europe, Britain included, while serving as Venetian envoy to Charles V (see fig. 3, p. 196). 
the international events he observed while travelling, mostly on horseback, through the German lands, the Low Countries, England, Spain, and France (e.g., Contarini 1525). Contarini was a first-hand witness to Venice's shifting position in continental affairs, from independent strength to relative powerlessness among European states. He was later the Venetian ambassador to the Holy See. Beyond diplomatic postings, he served the Republic - among other capacities - as one of the heads of the Council of Ten, where he dealt with myriad issues, including wheat provision, murder, censorship, and carrying concealed weapons. He became a member of the most prestigious and powerful steering committee of the Senate, the Collegio, where he served as a savio grande responsible for general governmental affairs. ${ }^{3}$ Made cardinal in 1535 , he advocated various proposals for internal reform of the church. He also gave his support to the emerging Jesuit order. Perhaps the highest point of his ecclesiastical career came in 1541, when he attended a conference of Catholic and Protestant theologians at Regensburg to see if their theological differences could be bridged. Contarini helped to draft a document on justification of salvation that both sides accepted, but the discussion reached an impasse when it came to sacraments, church structure, and the papacy. ${ }^{4} \mathrm{On}$ his return to Italy, the pope named him the legate/governor of Bologna. He died there the following year. Contarini was eventually interred in the family tomb in the Santa Maria dell'Orto church in Venice.

By all accounts, Contarini showed "a remarkable continuity" in public life as a devoted servant, first of Venice and then of the church (Gleason 1993, 90). A shrewd observer of diverse ways of life, he held firm to the ethos of his patrician class as well as to the faith of his church, moving with ease in the secular and ecclesiastical worlds. He accepted hierarchy and inequality but without failing to notice their shortcomings in Rome as in Venice. He gained, as Elisabeth Gleason notes, a reputation for being a fair-minded and skilled diplomat with a clear sense of when to take a stand and when to compromise. "His experience, self-confidence, and knowledge of psychology" (Gleason 1993, 44) were mirrored in the diplomatic reports he wrote while serving both Venice and Rome. Even when he was not consistent in his position - for example, his description of how a public official or bishop ought to behave did not always accord with his own behaviour when faced with the exigencies of office - few doubted his good will, sincerity, moderation, and strong sense of civic

3 For a glossary of governmental terms, see Appendix B.

$4 \mathrm{He}$ was tainted with Protestantism in the later years of his life, but his ecclesiastical work has received a less controversial and more positive re-evaluation since his death. See, more recently,the unsigned commentary on his life in L'Osservatore Romano (2017). 
duty. He succeeded in combining his various commitments "in an harmonious way" (Gleason 1993, 44, 67-71, 80-92; see also Contarini 1571; Gilbert 1969, 265; Negrato 2012).

In drafting De magistratibus et republica Venetorum, Contarini drew on both the history of Venice and his own experience to provide a host of normative, historic, and contemporary details that would educate Venetians and foreigners alike about the machinery of Venice's government. The volume was not concerned with the political behaviour of Venetians, but with the formal institutions by which political aims were realized. The reflections are thus as much a description of the institutions of governance as they are a prescription for how those institutions ought to work to meet expectations. In this way, De magistratibus contributed to a particular view in the sixteenth century that has come to be known by modern historians as "the myth of Venice," ${ }^{5}$ celebrating the Republic's well-being and accomplishments, and presenting its aspirations and self-image as reality.

What continues to lend support to Contarini's portrait is that, by his time, Venice had managed to preserve its liberty inviolate (unlike most other Italian states), had avoided long-lasting factional violence, and had experienced the benefits of established institutional forms of elite interaction and organizational ways of processing and addressing problems: what some modern social scientists studying the requirements for human development identify as "perpetually lived organizations" (North, Wallis, and Weingast 2013, 158). The Republic withstood and survived the 1509 attack on its liberty by an alliance of great powers known as the League of Cambrai. It has been suggested that Contarini's treatise was written in response to the Venetian defeat at Agnadello in 1509, to combat the sense of insecurity that had been mounting since 1500 and to restore confidence in the image of Venice as a serene and long-lasting republic (e.g., Bowd 1998, xv, and 196-7, 235, and supporting sources cited therein). By 1600 , support for the myth of Venice came from outside Venice as the political vicissitudes of the other Italian republics exposed them to absolutist rule and both Milan and Naples became part of the sprawling empire of Spain. The fate of the Italian peninsula was increasingly determined by large European territorial states (Bowd 2000a, 408-9). Against this backdrop, Brian Pullan found that now the political atmosphere in Italy favoured the myth of Venice, "for only Venice kept its old character and its republicanism and independence" (1964, 95). For "Venice endured as a republic while its neighbors did not, thus achieving for itself an

5 For an elaboration of this point, see Appendix A, "The Myth and Anti-myth of Venice." 
international reputation as a state in which the interests and passions of the citizens were almost mystically bound to the system of government ... Until its capture by Napoleon in 1797, Venice had been an independent community for nearly a millennium" (Muir 1981, 13).

Contarini may not have anticipated the success and influence of his work, which became a primary source of knowledge about Venice. Not only does his text capture the characteristics that make Venice unique, but the popularity of the text itself added to Venice's reputation and myth of greatness. The treatise was in circulation as a manuscript in France and Germany before its publication in 1543 in Paris (Bowd 2000b), and went through several reprints in the sixteenth century and beyond. Since the 1543 Latin edition published in Paris, other Latin editions followed: first at Basel in 1544 and 1547, and then at Venice in 1589 and 1592. The Elzevirs brought out new Latin editions in 1626, 1628, and 1722. A French translation by Jean Charrier first appeared at Paris in 1544 and later at Lyon in 1557. The first Italian translation, edited by E. Anditimi and offering a modified version of the Latin original, seems to have been published at Venice in 1544; others followed in 1548, 1551, 1564, 1591, and 1650 (Florio 2010; Fink 1945, 39n50; see also sixteenthcentury sources discussing Contarini in Cozzi 1963-4, 282-3). ${ }^{6}$ These reprints can be taken as proxy measures of the work's success in reaching readers throughout Europe. A more direct indication that Contarini was read in the sixteenth century is suggested by the research of Stephen Bowd (2000b). He found that "most sixteenth-century readers were full of praise for the work, which according to the first French translator, allowed the reader to understand how by a combination of prudence and good laws, Venice had resisted natural decline." Bowd quotes the French translator who in 1544 noted to his readers that "if you read this marvellous book (as I advise you to do) you may easily see Venice from [the comfort of] your home" (83n2).

De magistratibus captures both the characteristics that rendered the Republic of Venice unique among Italian city states and the significance of Venice "as a fermenting element" (Lane 1966a, 415) "in the political education of Europe" (Bouwsma 1973), by modelling a different way of organizing public affairs at a time when monarchical and absolute rulers dominated Europe and dictated political practices (see also Koenigsberger 1997; Pullan 1974; Venturi 1971, 1979). Contarini's De magistratibus sharply differs from Domenico Morosini's design of a well-managed republic in his work De bene instituta re publica, begun in 1497 but still unfinished at

6 Several Italian editions continue to be available (e.g., Conti, La Republica e i magistrati di Vinegia, 2003). 
the time of his death in 1509 (Finzi 1969). Like Contarini, Morosini was deeply attached to Venice and was concerned with the threat of domestic dissidence and faction among patricians. But unlike Contarini's, Morosini's treatise is "rambling and inconsistent" (Chambers and Pullan 2004, 66) and is unrealistic in its expectations of how a well-managed republic might be constituted. It was unrealistic for example to expect, as Morosini does, that factions can be eliminated and the whole of patrician citizens be of one mind both in accumulating wealth and in sharing a single conception of the common good (e.g., Cozzi 1970; King 2014, 140-50). Against this backdrop, it comes as no surprise that successive generations of scholars have recognized Contarini's treatise as "the most celebrated work ever composed on the Venetian government" (Libby 1973, 17; see also Gilbert 1967, 183; Muir 1981, 31; Romano 2007, xix), "with a traceable impact in many countries" (Pocock 1975, 320). In fact, it "became the great source that fed republican thought in monarchical centuries" (Gilbert 1967, 184; see also Pullan 1974; Voltaire, cited in Venturi 1979). In its long history as an organized political community, Venice had suffered no revolutionary change, and almost every institution of its government maintained deep and lived roots in the past. Venice had not styled itself as "the most serene and eternal Republic" for nothing.

The present volume, titled The Republic of Venice, is the first modern translation of the original Latin text available in Contarini's collected works, his Opera, which was published in Paris in 1571 under the supervision of his nephew, Alvise Contarini, then living in Paris as the Venetian ambassador. While some of his Opera's passages on theology were revised to allay the fear of inquisitors (Fragnito 1985, 31-43), this does not appear to be the case with De magistratibus, which is thought to be unexpurgated. Moreover, the Opera edition used for translating The Republic of Venice is the text that modern historians of Venice have often used in quoting Contarini from the Latin (e.g., Bouwsma 1968; Gleason 1993; Pocock 1975; Skinner 2002, 128). While remaining faithful to Contarini's Latin, the present translation is easily accessible to modern readers who wish to gain a first-hand appreciation of what it was that Contarini actually wrote that earned his treatise on Venice its status across the centuries. In this way, the present volume recovers for modern readers a classic work in the history of Venice and Renaissance Italy.

This is not the first time that De magistratibus has been published in English. That distinction was gained in 1599, when Lewes Lewkenor published the work in London under the title The Commonwealth and Government of Venice. But Lewkenor's edition was not a translation from the original and definitive Latin edition of 1571. As he himself admitted, he used the Italian version of 1544, and as philological research by Maria 
Stella Florio (2009) found, his translation was occasionally faulty. In addition, Lewkenor mistranslated, amplified, or deviated from the Italian text in several places in order to make the treatise more acceptable to the English. He interpolated an argument in favour of English civil liberties, and he also elected to use "commonwealth" rather than "republic," since the latter term was at the time rife with controversial assumptions (Florio 2009, 103-15). Lewkenor added eighty pages to the book, by including excerpts from five other books ${ }^{7}$ on Venice and by adding a list of the doges in chronological order. Imperfect as it is, Lewkenor's edition with its unmistakable Elizabethan prose has acquired historical value in its own right and remains a rich source for philologists studying English-Italian translations (e.g., Florio 2009, 2010; see also McPherson 1988). In 1969 the work was reprinted in a facsimile edition by Da Capo Press and the Theatrum Orbis Terrarum (Amsterdam and New York), but this reprint is no longer available. The 1599 English translation is now easily accessible through EEBO and Google Books, making it possible to compare and contrast this Elizabethan edition with our modern English translation, which is another project in itself. By going back and directly translating the original Latin, the present edition makes Contarini's actual text immediately accessible to modern readers.

In the remainder of this introduction I present Contarini's portrait of Venice, with both its strengths and its weaknesses, and then examine the extent to which his analysis illuminates the factors that account for Venice's status as "a stable oasis" (Dursteler 2013,5) in the peninsula and a source of envy throughout much of Europe (sources cited in, e.g., Pullan 1974, 453; see also Wills 2001).

\section{Reality and Myths}

Contarini divided his treatise into five "books" or chapters of various lengths. The first deals with the location and origins of the city of Venice and the form of its governmental system, focusing on the basic political institution, the Great Council (Maggior Consiglio). The second book

7 Of these, perhaps the most noteworthy excerpts are taken from Donato Giannotti's Libro della Repubblica de' Veneziani ([1540] 1840). Giannotti, who wrote his book during a sojourn in Venice and Padua in 1525-6, read widely and discussed his topic with various Venetian gentlemen, possibly including Contarini himself. He reinforces the work of Contarini on many points. As William J. Bouwsma notes, Giannotti differs from Contarini in that the former's book "is less lofty and academic, and less concerned to inspire feelings of awe, more concrete, more interested in practical details. Above all, Giannotti adds to Contarini's vision of static perfection a realistic awareness of historical development" $(1973,154)$. 
discusses the office, election, and prerogatives of the doge as the head of state and chief magistrate. The third and fourth books discuss the Senate, the Council of Ten, and the main judicial tribunals and various magistracies. The final book concludes with a discussion of the government of the Venetian terraferma and various community organizations. In sum, The Republic of Venice clearly lays out the complex structure of the machinery of government and puts the Venetian experience in a philosophical context, inviting comparative historical and contemporary analysis.

Contarini began his treatment in book 1 by recalling that he had often noticed that foreigners visiting the city for the first time were admiring of and astonished by the magnificence of Venice. One such foreigner was a Sicilian nobleman, the prince of Bisignano, who described it as "a truly excellent city," a description duly recorded by Marin Sanudo in his diary of 23 June 1521 (cited in Labalme and White 2008 and used on their book cover). Contarini then drew attention to geography's importance in creating an advantageous and secure location for the city. Very few cities, in fact, had been founded on sites as opportune as that of Venice. He described in some detail how Venice's location attracted people seeking refuge from calamities elsewhere in Italy. "Fortified by a marvelous expedient of nature," Venice thus was safe from attack from land and sea (book 1:8). This location made Venice equally well positioned for trading with others and amassing an abundance of commodities for its citizens. But these factors were not enough. Echoing Aristotle, whose work he was said to know by memory, Contarini observed that "a city is more than just walls and houses" (book 1:10). Thus, more important than geography per se was the use of environmental resources to create organized existence that revealed human creativity, or what Jacob Grygiel $(2006,22)$ recently characterized as "the human factor within geography." "Centuries of creative energy" (Crouzet-Pavan 2002, 10; see also McNeill 1974, chap. 2) went into what Contarini referred to as the "system and form of government by which men attain a happy life" (book 1:10). The rest of The Republic Venice is devoted to a description of the imaginative ways Venetians organized their system and form of government.

Venice was not, Contarini noted, "the work of immortal gods but rather of men" (book 1:3). For he noted (in book 1:11) that Venetians were not like "famous philosophers, who created forms of government according to the desires of the mind." Venetians were the co-creators of the institutional world in which successive generations of people lived. Despite his piety, Contarini dismissed the view that the Venetian Republic rested on divine will or miraculous origin, ${ }^{8}$ which was an ancient myth of Venice

8 See also the accompanying note on translation by Giuseppe Pezzini in which he shows that Contarini pruned his Latin vocabulary of Christian and vernacular borrowings. 
(see Fasoli 1958; Gaeta 1961, 59; Muir 1981, chap. 1; Rose 1974, 479). Contarini did not call up Saint Mark or the Virgin Mary to explain why Venice became a great republic, though there is little doubt that "the cult of Saint Mark strengthened [the] feeling of sovereign independence" (Lane 1973, 88) and was "the nucleus of Venetian civic consciousness, a nexus of popular piety and patriotism" (Muir 1981, 78-92, 299). Similarly, in spite of being a patrician from an old Venetian family, Contarini did not claim that Venetians succeeded where other Italians had failed because of the faith or virtues of the former. He invoked Aristotle and Plato from time to time and demonstrates familiarity with medieval political ideas, but it is generally agreed that political writers of the twelve and thirteenth centuries seemed to have little or no influence in Venice during the formulation of its constitutional arrangements - although there was considerable ex post facto praise of the sort of balanced constitution that Venice was supposed to have created (Lane 1966b, 306).

Contarini attributed the organizational arrangements of the Venetian republic to "wise and prudent ancestors" and mundane political acumen that brought together ideas and practices over time. He may have made too much of the "wise and prudent ancestors" in his narrative. But, as has been noted, "'the wise ancestors' to whom Contarini attributed the merits of Venetian government were not writers on political theory or architects of utopian states; they were practical men of quotidian politics who build the constitution piecemeal, responding to immediate problems as they perceived them" (Gordon 1999, 137). John G.A. Pocock echoed the same idea when he observed that "Venetian history proceeds through pragmatic reflection on past experience, and far from hitting upon some miraculous recombination of elements, displays in 1170 a political sagacity exceeding that of the Roman patricians after the expulsion of the kings" $(1975,281) .{ }^{9}$ In fact, Contarini points to a long tradition of equating experience with age, for "the slow-moving Venetian cursus honorum tended to weed out men who were brash, favoring instead those who were given to compromise and deliberation" (Romano 2007, 330; see also Finlay 1980, 134-7). Contarini also reached into the past to advance a moralizing and educational agenda: the enhancement of the Republic's independence and stability that had become all the more important following the War of the League of Cambrai, when its position in European affairs was being

9 It is not entirely clear what event in 1170 Pocock has in mind. Most likely it was the creation of the Grand Council (Pocock 1975, 279). At about the same time, in 1172, the dogeship changed into a magistracy, and 1178 saw the creation of ducal councillors coming from each of the sestieri into which the city was divided (Lane 1973, 92, 96). In Venetian constitutional history the 1170 s were indeed "a critical moment" (Pocock 1975, 279). 
challenged and eclipsed by the growth of national monarchies (see also Gilbert 1969). Appeals to wise and prudent ancestors was thus a way to reiterate the view of history promoted by Cicero and widely accepted until the Enlightenment: that history is both a life of memory and a mistress of life (historia magistra vitae est) (see also Sabetti 2010, 66).

Equally important, Contarini stressed that Venice was not created by a "hero legislator" (Pocock 1975, 280) or absolute ruler, but by many individuals across generations. Recent research supports the view that the development of both the patriciate and the various institutions of governance was an ongoing process (e.g., Chojnacki 2000; Rösch 2000). Contarini admitted that "more than a few [cities] in the past centuries have surpassed the city of Venice in the extent of their dominion, the number of people, and the abundance and magnificence of material things" (book 1:1). But, as noted earlier, a city is more than "just walls and houses"; "the city is specifically the system and form of government by which men attain a happy life." And it is this "outstanding" and "marvelous quality" that "makes Venice especially shine, seeming to surpass antiquity," for "none can compare with this city of ours in institutions and laws suitable for living well and happily." No other city has "ever endured for such a long time" (book 1:10; see also 2:33 and 4:76).

Contarini here hints at (but does not develop) something that the modern literature on city origins and economic development has, arguably, established: that prosperous cities came first, and rural development followed later. Contarini did not, and could not be expected to, cover Venice as a commercial republic. But because of its lagoon foundation the Venetian commercial republic developed in the reverse of the traditional economic model, ${ }^{10}$ which starts from agriculture and progresses to manufacturing, service, and a knowledge economy. Venice began with a transportation service economy, trading salt and fish for grain to become what has been aptly described as a "forest on the sea" (Appuhn 2009; see also Griffith 2004; Lane 1973, 1). Already by the thirteenth century Venice's knowledge industry was at the forefront of developments affecting changing social relations and the circulation of ideas and architectural designs in western Europe (e.g., Febvre and Martin 2010). Focusing on the architectural imagination, Sophia Psarra recalls that by the

10 A point that Machiavelli also noted but did not quite seem to appreciate when in The Discourses $(1,55)$ he observed that "gentlemen in this republic [i.e., Venice] are so in name rather in point of fact: for they do not derive any considerable income from estates; their great wealth is based on merchandise and movable goods. Moreover, none of them have castles nor have they any [feudal] jurisdiction over men" (2003, 247-8). Cf. the impression of Venetian gentlemen in Thomas Koryat's account [1611] 1905, vol. 1. See also Jacobs 1970, 18-19; Sabetti 2010, chaps. 5 and 7. 
sixteenth century "Venice and the Veneto were home to more than 450 printers, publishers and booksellers, who fueled with books, woodcuts and engravings the interest in the ancient world shown by architects and scholars" (2018: 7). The nobility of Venice was for the most part made up of merchants, traders, printers, and writers. ${ }^{11}$

Contarini advances a temporal and secular view of republican government with particular twists. First, unlike other parts of Italy, Venice had never been conquered or occupied, and alternations in rule were achieved not through assassination but via the ballot box. Second, Venetian republicanism reinforces the view that there is not a single scale on which a republican discourse can be weighted and classified. ${ }^{12}$ Until the fourteenth century, the term republica retained the old meaning of any legitimate form of government, thus applying to a wide variety of regimes (see, e.g., Leonardo Bruni cited in Hankins 2010, 464). In the course of the fifteenth century the term and the accompanying "republican idea" came to refer almost exclusively to non-monarchical regimes, even if at times it included different forms of oligarchies, like those of Florence, Lucca, and Venice (Hankins 2010, 465). As William J. Connell notes in his discussion of the republican idea in the Renaissance, "it bears keeping in mind that oligarchies are still republics, and there is still something distinctly different about the rule of a self-governing, self-legitimating oligarchy as compared with the rule of a monarch or a tyrant" (Connell 2000, 25).

A distinctive feature of Venetian republicanism repeatedly noted by Contarini was that the political imaginary and repertoire shared by patricians - what in modern social science is called shared understanding, cognitive rules, and epistemic knowledge (V. Ostrom 1997, chap. 4; see also Greif and Mokyr 2017; Sabetti 2010, chap. 6) - possessed no single centre of authority with the final say over public affairs (e.g., Contarini,

11 Some Asian diplomats, inspired by the work of Frederick C. Lane, have suggested Singapore as the new Venice of the twenty-first century (e.g.,Koh 1998). Economists Daron Acemoglu and James A. Robinson (2012, 152-8) argue the opposite, that Venice "became a museum" by the fourteenth century. Unfortunately, their exploration of the Republic of Venice is conducted at such a high level of generality that the discussion misleads and undermines what they sought to do, to understand the origins of power, prosperity, and poverty in the modern world. More recently, Chrystia Freeland (2012), by uncritically building her argument on their analysis, makes the same error.

12 A point made more generally by several contributors to van Gelderen and Skinner's (2002) two-volume study of republicanism as a shared European heritage. One contributor, Donald Winch, suggests that even when confined to Scottish thinkers alone, the term "republican" is "a sophisticated term of political and interpretative art" to challenge how best to make sense of particular conceptualizations: "civic or moral humanism," "Commonweathmen," "Country" forms of opposition, "neo-Harringtonian or ne-Roman ideology," or more simply, "classical republicanism" (294). 
book 4:73). The shared understanding among patricians and the very practice of governance excluded the notion of an undivided, monocentric conception of political rule. What Venice had was corporate rule. As Dennis Romano recalls, "especially between the fourteenth and seventeenth centuries, as the European state system took shape and matured under the tutelage of kings seeking to fulfil their dynastic ambitions, Venice served as the model for an alternative pathway to political development, one based upon republican rather than monarchical principles, and in so doing garnered great admiration for the stability and constancy of its regime" (2007, xix). What Romano describes adds to the significance of Venice in history (Pullan 1974), and it helps to explain why, for observers like James Harrington in the seventeenth century and Voltaire in the eighteenth, Venice remained a model of liberty to be admired, esteemed, and if possible emulated (Harrington [1656] 1992, 34; Venturi 1979, 209). For this reason, Contarini's book may have prominence in early modern political thought: it shows how it was possible to have lived institutional arrangements that could serve as constitutional and political alternatives to national monarchies and monocentric states and, and at the same time, hold violence in check. Contarini's account demonstrated that violence could be reined in by non-centralized systems of rule (see also Pocock 1975, chap. 11; Wilson 2016; cf. North et al. 2013).

At the same time, Contarini saw patrician rule as unproblematic. He held the then-widespread view, both in and beyond Venice, that not everyone who lived in the city was, and should be regarded as, a citizen. The population of Venice was divided into three social orders (see Pullan 1999). First, the status of citizen was confined to those of noble birth and, in some cases, those who acted meritoriously towards the Republic (book 1:17-18). Citizens were free men, whereas those who worked for a wage were under some form of servitude (book 1:17). Contarini refers to the hereditary patriciate as the "citizens" in Latin, but there were others immediately below the patriciates known as cittadini originari. These were the second level of elites who held bureaucratic posts as secretaries and state notaries but did not have political rights. These original citizens were also a hereditary class enrolled in the silver book, just as the nobility were enrolled in the golden book (Edward Muir, personal communication, 14 March 2017; Pullan 1971, 103-5). Brian Pullan notes that to some extent, noblemen and citizens did intermarry, though it caused some concern in the seventeenth century as patricians seeking to alleviate financial difficulties took wealth from below by marriage $(1971,106)$. Only the third layer of residents, the common people below both the patriciate and the cittadini originari, were excluded from participation in the governance of the city.

Contarini's defence of the patricians' natural position to govern with the aid of cittadini originari, his support for the exclusion of the common 
people from a share in the conduct of the Venetian government, and, more generally, his acceptance of the unequal social and political conditions among Venetians - all of these were unexceptional at the time. He offered the standard justification, used as far back as the ancient Greek city states and as late as the end of nineteenth-century Europe, to confine political participation to a select few and exclude the great majority of people: namely, the assumption that humans possessed varying and unequal qualities, abilities, and endowments, and hence only some were fit to rule (e.g., Bagehot [1867] 1968, 272; Wilson 2016, 240; cf. Brennan 2017). For Contarini, as for Aristotle and Plato and medieval writers and more recent analysts like Walter Bagehot, the unequal distribution of human qualities, abilities, and endowments resembled that found in the human body and the physical, natural world. Contarini applied this analogical way of reasoning to politics and religion. In book 1, he observed: "consider that a living creature has been shaped by nature in the same way that a city is organized by men. In a living creature, there are many parts which are not alive, and yet the creature needs them in order to survive" (1:17; 5:97-8; see also Bowd 1998, 203-10).

What was particularly Venetian in Contarini's defence of the city's hierarchic arrangement and social inequality was his depiction of the ancestors from whom his generation had received such a flourishing republic. As Contarini described them, these were people "without exception of the same mind in their desire to strengthen and advance the country, almost without regard for their own private benefit and personal honour." They "were never ambitious when it came to themselves, and were infinitely more devoted to the well-being of the country" (book 1:10). Research by Brian Pullan on caring for the poor draws attention to the complex interplay of religious and secular reasons that gave expression to Contarini's assertion: a highly developed sense of the state as "an entity binding rulers and rules, a corporate political enterprise demanding service and self-sacrifice," for the public offices were not "intended to be primarily a source of gain or a means of rewarding private persons" 1960, 20, 32). But no matter how sage, selfless, and devoted to the public good any particular individuals might have been, the view that the entire Venetian patriciate was wholly and consistently patriotic, self-sacrificing, devoted to civic-minded service, decorous, and wise is difficult to accept.

What allowed Contarini to convey the image of a timeless and serene Republic with a selfless patriciate was his tendency to fuse time, brushing aside tumultuous events in the history of Venice that challenged such a portrayal. Edward Muir notes that "the early political history of Venice was certainly violent enough." He adds that "if the chronicles can be trusted, between 697 and 1172, five doges ... were forced to abdicate, nine exiled or deposed, five blinded and five murdered. The early doges and their 
families were famous for their involvement in conspiracies and vendettas" $(1999,384)$. Other turbulent events, elided by Contarini, include the conspiracy to overthrow the constitution involving Doge Marin Falier in 1355; the decades of doubt brought about by the wars against Genoa in the fourteenth century; the repeated challenges to Venice posed by the Ottoman Empire in the fifteenth and sixteenth centuries; and the future stagnation, decay, and despair among rich and poor patricians revealed by the constitutional crisis of 1628-9 (see, e.g., Rose 1974; see also Romano 2007).

Modern research has seriously challenged the image of a Venetian patriciate endowed with unparalleled self-possession and selfless devotion to public service that Contarini sketched and that many foreign observers believed. Research by Donald E. Queller documents - with what a reviewer called "cascades of evidence" (Chojnacki 1988, 601) - that "Venetian nobles were deterred by no spirit of sacrifice in their zeal for the public welfare" $(1986,147)$. Queller produces many instances that call into question Contarini's depiction of patricians over the centuries as extraordinarily patriotic and altruistic, and seeks to replace that depiction with a view of the patricians as essentially self- and rent-seeking. Robert Finlay's research notes that many patricians in the sixteenth century campaigned relentlessly for public positions, electioneering, cheating, conspiring, and bribing to gain desirable offices and avoid undesirable ones; and the leadership of the Republic tended to be kept in the hands of some factions prominent patricians in the Senate, the so-called primi di la terra - and not in the hands of the "common" patricians in the Great Council (1980, chap. 1 and 200-286; Queller 1986, 118, 189). Contarini took justifiable pride in drawing attention to an "ancient" aspect of the Venetian judicial system (book 3:65-6) that allowed poor defendants the right to statefunded counsel, but he did not reveal what we now know from scholarly sources: he failed to notice that there were less meritorious, class-based features of the justice system that put most ordinary Venetians at a disadvantage (e.g., Ruggiero 1980; Shaw 2006). But there is more.

The Venetian legislation, as Queller (1986, chaps. 3-7) suggests, can equally be taken to demonstrate that the Venetian governing class sought to curb the evasion of public responsibilities and opportunistic tendencies among its members. The legislation conveys "the remarkable degree to which Venetians sought to find some solution to the human frailties that made them as imperfect as others" (Muir 1988, 290). At the same time, the electioneering and canvassing for votes highlighted by Finlay must not have appeared as a defect to many young patricians: those activities helped them to lessen the cost of securing information about and to increase the value of their vote. Dorit Raines's (1991, 140-5, 161-2; 2003) research on those Venetian practices recalls what is familiar to modern students 
of electoral and legislative politics in and beyond the American Congress for voters and legislators alike, to be well informed is not cost free, but requires a considerable outlay of time and effort; the modern folk theory of democracy glosses over the dark realities of democratic politics (Achen and Bartels 2017; Brennan 2017). In the words of one reviewer, Finlay "does not seem to have made up his mind ... whether to treat electoral corruption as a positive or a negative factor, as an essential part of the system or a threat to it. He does not seem to have decided whether to argue that the Venetian political system was essentially stable, capable of absorbing conflict and of being altered in matters of detail to avoid structural changes, or whether the crisis of the early 16 th century led to a real change of system" (Burke 1980, 22). Still, Contarini himself was aware of, and drew attention to, the potential for human fallibility, political corruption, and institutional weaknesses and failures throughout his treatise.

In book 1, Contarini noted that "men endowed with both prudence and integrity are extremely rare, and men generally err in judging because the force of the mind's passions tends to powerfully divert from the right judgment ... [for] man's nature is mortal and frail ... and easily succumbs to his frail disposition" (1:14-15). He recognized that procedures and rules for admission to the Great Council needed to avoid fraud and prevent "some ignoble person from stealthily creeping in their congregation of gentlemen" (1:20). He also acknowledged the challenge of maintaining honest elections, without voting irregularities. Elections in the Great Council were suspended after sunset precisely to prevent patricians from committing "any illicit acts under the cover of darkness" $(1: 28,29,30)$. A principal reason that public power was vested in and alternated between so many hands was precisely to minimize the potential that those who were excluded would "plot something" against the Republic (1:29). He allowed that even the doge could be bribed (2:29, $36,38)$. In book 3 , Contarini recognized different motives, interests, and knowledge among senators (3:55), and in book 4, concerning the magistracies of the Republic, he saw the possibility of patricians being convicted for embezzling public money and converting it into private wealth $(4: 78-9,80,94)$. In book 5 , he noted the prospect of arrogance and mischievousness among patricians if they were allowed to command a large number of attendants, since "it is human nature to incline to the worse" (5:94). Recalling Aristotle, he conceded what Montesquieu and Madison and Hamilton in The Federalist would later place in sharp relief: "such is our human disposition that those who are in power do not conduct themselves well unless they are checked by another authority" (5:98). In the same book, he noted that "many young men, corrupted by ambition or luxury since the expansion of the empire, have neglected" their 
duties (5:96). Finally, Contarini recognized that no matter how perfectly things may have been originally constituted, after some time everything experiences "the crumbling deterioration of nature and stands in need of repair" (5:96), for "nature has disposed things in such a way that nothing can be permanent among men" (5:96).

In brief, Contarini's book may have promoted a certain idealized view of Venice that some historians call "the myth of Venice," but its author also gave reasons to question it. His work did not just convey the image of a perennially harmonious republic. He was aware of the contrast between expectations and practice in the face of exigencies of security, though he "did not fear that the Council of Ten might become tyrannical" (Gleason 1993, 66). The emphasis on the complex system of chance and choice in elections can be viewed as indications of efforts to discourage arbitrary behaviour (Jones 1997, 93) and to make personal virtue the automatic or routinized consequence of the elections and institutional balances - what John Pocock calls "mechanized virtue" (1975, 284; see also Conti 2002; de Vivo 2007, 27). One also suspects that Contarini was not troubled by the discrepancy between the ideal and the reality of Venetian institutions for other reasons. One reason might be that corruption actually facilitated stability because it gave some, often poor, nobles a vested interest in the election process from which they might profit. Elections might be another kind of patronage/clientage system (see Burke 1980; Muir 2017). Another reason, for Contarini, was that the very reality of Venice was itself a mental creation that served to shape action; and, like officials in the Holy Roman Empire of his time (Wilson 2016, 45), he tended to consider that discrepancy between reality and appearance to be an expression of the imperfection of the human condition itself. At the same time, Queller's preoccupation with discrediting the "myth" distracted him from "confronting the structural issue at the heart of the myth, which is the tension between the patriciate as a regime and the patriciate as collection of flawed individuals between patrician ideology and patricians' behavior" (Chojnacki 1988, $601)$. Similarly, from the perspective of those who study modern institutions for collective action, the tensions highlighted by both Queller and Finlay are unsurprising for several reasons (e.g., Fotos 2017; E. Ostrom 1990, 2005, 2014; Sabetti 2000). All human interests are rooted in the self, and a function of the political process is the extent to which it is possible to bias individual decision making towards taking into account a wider community of people and longer time horizon. Moreover, bureaucratic politics and corruption can be viewed as permanent features of government organizations. For these reasons students of institutions for collective action would expect Venetian governance to experience weakness and failure, and to find some patricians shirking responsibility, 
pursuing ambition, and engaging in corrupt practices. They would also expect that the substantial social and economic disparities among social orders would show in the way that members of those orders experienced the application of different standards in criminal law.

\section{Beyond Myths}

The contrasts between the norms and practices of Venetian governance, between how the order of patricians were supposed to behave and how they individually sometimes actually behaved, highlight ex adverso Contarini's message of institutional resilience and political stability - for, in the words of Margaret L. King, "it would be foolish ... to deny that Venice ... was a uniquely successful city" (2014, xix). So the question about long-enduring institutions becomes: How was it that Venetian institutions "proved strong enough to absorb many shocks without violent revolution" (Lane 1973, 186)? This question can itself be refined further to ask: How did the Republic of Venice largely manage to avoid the bloody factional violence and battles characteristic of other parts of Italy, and maintain a semblance of liberty not found elsewhere in most of Europe (Muir 1999; Terpstra 2006, 5)? And in the words of modern social science advanced by, among others, the Bloomington school of political economy (e.g., E. Ostrom 1990; Sabetti and Aligica 2014; see also Voigt 2013), how is it possible for fallible human beings to construct and operate an enduring system of governance? It would be too much to expect Contarini to provide a response that would meet twenty-first-century standards of scholarship. His work does not match those standards, and it may be anachronistic to hold him to them.

For Contarini the key to the strength and success of the Republic lay in its combination of Aristotle's and, later, Polybius's three forms of ideal rule: the doge offering the monarchical element, the Senate the aristocratic, and the Great Council the democratic. This is the idea of mixed government (e.g., Casini 2002; Gaille 2005). This conception permeates Contarini's treatise and is used to account for the success of the Republic but, I argue (see also Pullan 1974), this is not the whole story about why the government of Venice endured. In fact, it can be argued that Contarini's analysis itself points to additional factors as determinants of stability and institutional longevity, and that these factors have been addressed at some length in the later social science literature on what makes institutions work and endure (e.g., E. Ostrom 1990; Rodrik 2002; Tocqueville [1835] 1969, 1, chap. 9).

This literature identifies three factors as the "deep determinants" that account for the durability of political regimes: geography; institutions; and trust, or the habits of the heart and mind that animate institutions. Each set of factors has different functions, and they all supplement each other 
in complex fashion. The literature, starting with Tocqueville, argues that institutions are more important than geography, while habits of heart and mind are more important than geography and institutions for making institutions work well and endure. This social science conclusion seems echoed by historian Edward Muir when he observed that "a well-ordered system of magistracies ... was insufficient to maintain political stability without an auxiliary ethic of political service" $(1981,21)$. While there are differences between the modern self-governing institutions noted by institutionalists like Douglass C. North, John Wallis, and Barry Weingast, Vincent and Elinor Ostrom, and Tocqueville, and the institutions discussed by Contarini, it is nonetheless apparent that Contarini's approach to understanding political and institutional stability, as we shall see when we turn to the text, shares or seems to be informed by, mutatis mutandis, similar characteristics.

We saw earlier that Contarini focused, as a point of departure, on the importance of geography for understanding the advantages and disadvantages posed by a country's location (see Crouzet-Pavan 2002; see also $2000,2013)$. Contarini devoted a large portion of his work to describing, in effect, the importance of institutions in shaping the habits of the heart and mind in order for Venice to remain "secure not only from the domination of foreign men, but also from significant civil sedition" (book 5:104). He continued in book 5, "this has not been achieved by force, armed garrison, or a well-fortified citadel but rather by a just and balanced system of government such that the people obey the nobility of their own accord and do not wish for any revolution, while retaining a strong affection toward the nobility" (5:104). The compound system of rule is conveyed in Figure 1.

The Pien Collegio was the executive body and consisted of the Consulta and the Signoria. The Consulta involved six savi grandi, five savi di terraferma, and five savii agli ordini. The savi grandi were the highest-ranking members of the Collegio; the savi di terraferma were responsible for military affairs on the mainland; and the savi agli ordini were responsible for maritime affairs and by the sixteenth century were the lowest-ranking members of the Collegio. All the savi (literally, wise men) were individually elected by the Senate for a six-month term.

The diagrammatic depictions of the relations among those bodies help us to appreciate the complex organization of the Venetian system of government, but, in the words of one economic historian, they

mislead more than they inform because their membership composition covers the whole range of possible relations - in the language of set theory, they display, in various cases, independence, identity, inclusiveness, and intersection. Unless it were complex to the point of incomprehensibility, 


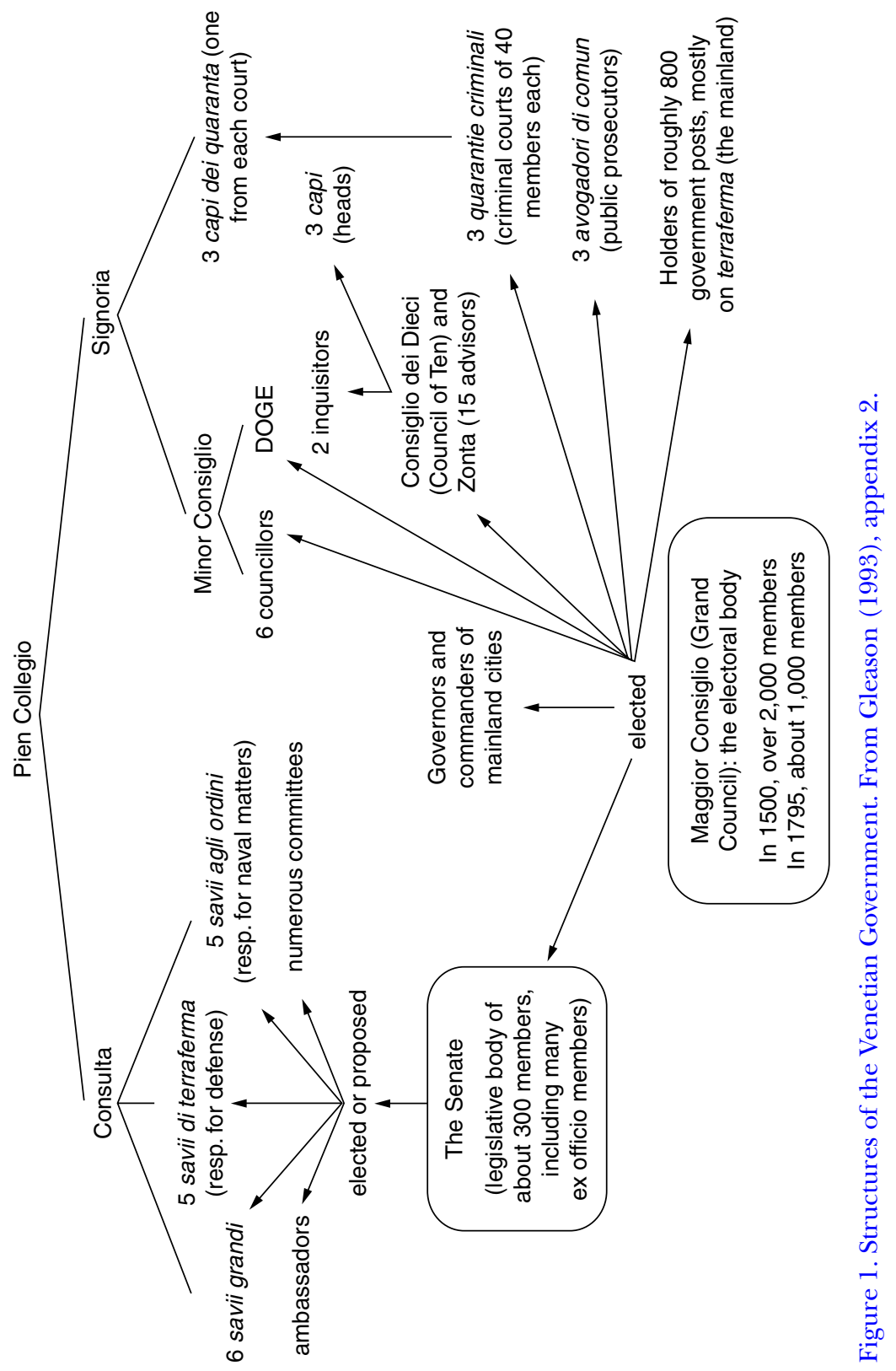


a diagram would also fail to capture other essential features of the Venetian system, such as short, staggered, terms of office of most officials, the complex method of election, the frequent practice of electing a person to office in a different body upon the conclusion of his service in another one, the restrictions that did not permit more than one member of a family to hold simultaneous office in the smaller councils and so forth. (Gordon 1999, 138-9)

The basic point is that Venice had a complex system of plural centres of powers.

Contarini described at some length the intricate mechanisms of elections that governed public affairs and goes into great detail about the selection and voting procedures, and how members drew balls from particular urns. Electoral mechanisms can best be understood as part of a larger system of multiple centres of decision and authority. Book 2 , in particular, describes the system of electing a doge as simultaneously an effective technique to prevent elections from being rigged and a means of ensuring broad support for the person ultimately chosen. Lane $(1973,111)$ represents this procedure for the election of the doge as follows:

From the Great Council there were chosen by lot 30;

The 30 were reduced by lot to 9 ;

The 9 named 40;

The 40 were reduced by lot to 12 ;

The 12 named 25;

The 25 were reduced by lot to 9 ;

The 9 named 45;

The 45 were reduced by lot to 11 ;

The 11 named 41;

The 41 nominated the doge,

For approval by the Assembly. ${ }^{13}$

13 Scott Gordon presents a simplified schematic description of the procedure as follows:

$30 \mathrm{~L} \rightarrow 9 \mathrm{~L} \rightarrow 40 \mathrm{E} \rightarrow 12 \mathrm{~L} \rightarrow 25 \mathrm{E} \rightarrow 9 \mathrm{~L} \rightarrow 45 \mathrm{E} \rightarrow 11 \mathrm{~L} \rightarrow 41 \mathrm{E} \rightarrow \mathrm{D}$

$L$ refers to selection by lot, $E$ to selection by election. 
Contarini suggests that the electoral system succeeded in preventing rigging by generating considerable discussion of the leading candidates for office. As Dennis Romano notes, appropriately in my view, "the procedure for electing the doge was not a perverse joke or a mere flight of fancy: it was carefully designed to reduce the danger of factional interference in elections by incorporating a generous element of chance. The several rounds of lottery made it difficult for anyone to guarantee that he or his allies would have a place in the nominating committees. Chance served to underscore the essential equality of all members of the Great Council" (2007, 37). Even when the doge was elected, he could still not conduct state business on his own initiative. He wielded power with others while retaining all the pomp of a revered and dignified leader. The doge's wealth was audited after his death to insure that he did not profit from his office. There is another aspect of the decision-making process that merits recognition: the importance of delay and consultation in slowing down the process of deliberation to defuse passion or, in other words, the importance of time in gaining reflection. In a fine study of James Madison's thought, Greg Weiner characterizes the natural power of time in deliberation as "temporal republicanism" (2012, ix), and it seems that this form of temporal republicanism was also at work in the Republic of Venice and can be read into Contarini's treatise.

The electoral process, rotation in office for magistracies below the doge, and multiplicity of individual magistracies remained practically unchanged from the thirteenth century onward in Venetian history. More than simply a system of "mixed" government, as Contarini suggests, these institutional arrangements as well as temporal delay contributed to the system of checks and balances. Of course, the system was not free of bureaucratic conflict, organizational rivalry, and time-consuming negotiations. But together, Contarini hinted, the electoral system and the checks and balances inherent in the system of government sought to do three things: secure a high degree of reflection and support among patricians, minimize the danger of factional politics and violence, and make the authority of governing accountable. The basic point is that Venice had achieved and perfected an equilibrium of plural centres of powers, and that sovereignty understood in Hobbesian terms or as monocratic rule is a concept inapplicable to the governance of Venice.

Contarini draws attention to the dynamic aspects of system performance, but he does not - and could not have been expected to - deal with possible trade-offs between different aspects of system performance in the temporal republicanism of Venice. Contarini's biographer, Elisabeth Gleason, suggests that his stands show he sometimes prized efficiency and order in the day-to-day workings of the government and did 
not fear that the Council of Ten might become tyrannical (1993, 66). Two types of trade-offs are in fact particularly important to Contarini's analysis of the workings of the Venetian machinery of governance. The first is concerned with a trade-off between efficiency and stability or durability. To attain maximum performance with regard to a particular set of criteria - say, rapid rotation in office, lengthy voting procedures - the rules and norms of a system would have to be aligned to those criteria to the point that the entire system of government could become vulnerable to fluctuations and disturbance in other areas. A second issue not discussed by Contarini is the possibility of trade-offs between criteria. Durability is always construed with reference to a particular set of criteria. In other words, the Venetian Republic could not be strong or robust in the face of all types of disturbances at all times. The procedure for electing the doge bet more on stability than efficiency. Thus, building stability with regard to a particular set of criteria - how to avoid factional politics and domination by one particular group - can and did make the system vulnerable to other criteria.

Historians have generated many case studies pointing to these issues and problems in the long history of the Republic. Over time, Venetians themselves came to realize that what applied to elections and office rotation did not and could not apply, for example, to questions of defence. When drawing up an order of battle in naval defence, or setting up land fortifications through the provveditori alle fortezze, one found that elaborate group discussions did not work well (see Hale 1971; Mallett 1973). Finlay highlights these challenges employing concepts more familiar to historians:

Venice's flaws were indissolubly linked to its virtues ... rapid rotation in office, diverse responsibilities within individual magistracies, dedication to collective decision making, a multitude of temporary commissions, overlapping competencies of councils, complex and lengthy voting procedures, and a consistent weakness of executive authority at almost all levels of government. Inefficiency, confusion and bureaucratic conflict were prices that Venetian patricians were apparently willing to pay for maintaining their republican order. $(1980,38)$

Though Contarini does not tell us so, we can surmise, judging by the long-term sustainability of the Republic, that the Venetians had somehow addressed and resolved the trade-offs between multiple criteria of institutional performance (see also Appuhn 2009 on environmental issues).

At the same time, Contarini was aware that the strength of the government of Venice did not derive just from a secure geographical location 
and the excellence of its institutions and laws. In fact, he suggested that its strength derived more from the set of attitudes, beliefs, sentiments, and rituals that gave order and meaning to the political architecture and process and provided the underlying assumptions and rules that governed them and instilled and nurtured support. As he noted, "it is something hard to believe, indeed scarcely credible, that for so many years the multitude, though deprived of a place in government, has never yet refused or been unwilling to support the government of the patricians" (book 5:98). And then he immediately suggested that the loyalty of the common people also rested in letting them share in "the offices and charges that could be entrusted to them without detriment to the common good" (5:99).

Contarini discussed a chief reason for the strength of the social and political order in books 4 and 5 . Research has abundantly demonstrated over the last four decades that the Venetian social order was characterized by the existence of a thick web of religious, charitable, and occupational institutions within and beyond the parish level. These institutions served as an essential foundation for the cultivation of the arts and of the practice of crafting institutions and neighbourhood associations of all sorts (see also map 3 on public buildings and facilities and map 4 on the Venetian administrative divisions). This polycentric and shared system of governance was "the foundation stone of Venice's social stability" (Lane 1973, 12; see also Fortini Brown 1987; Humphrey and Mackenney 1986; Martin and Romano 2000, 24; Pullan 1971; Psarra 2018, 52-65). The presence of these neighbourhood associations helps to understand why there was no sedition among the lower classes (Pullan 1971, 106-8).

The first scuole, which Contarini refers to as societies or companies (book 5:103), were founded in the thirteenth century as clubs in which members could worship together, providing charity for the poor and mutual aid for each another. By the sixteenth century, there were six big companies (the scuole grandi) and many smaller ones. The scuole grandi were reserved for the cittadini originari. Begun as pious flagellant companies for the well-to-do, these associations were principally charitable institutions that supplied processioners for public rituals, housed the poor, and engaged in other kinds of charitable activities. While nobles could be (and often were) members of the scuole grandi, only non-nobles could hold office in these associations. Members of the scuole grandi presented the greatest revolutionary danger to the nobility. Artisans per se were usually not members; they were generally members of the scuole piccolo, which were linked to guilds and specific trades (Lane 1973, 105-6; Muir 2017; Pullan 1971, 55). On the other hand, the internal organization of each scuola was modelled on the constitution of the Venetian republic - even 
in some cases copying the outfits and regalia of the government's officers. Similarly, just as the Republic was represented symbolically by the relic of St Mark, each of the scuole grandi had its own prized relics. In this way, "each [scuola] became a kind of mini-Venice" (Wills 2001, 125). It has been suggested that "an important reason why [ordinary] Venetians quietly accepted patrician rule was that the government itself offered them a measure of political involvement along with a form of social security" (Finlay 1980, 47). This helps to account for the loyalty the peasantry showed to Venice during the War of the League of Cambrai and for Contarini's warm portrait of terraferma loyalty in book 5 .

While institutions like the scuole helped integrate different elements of the city's population by imitating the Republic's central institutions, something similar was observable in the Venetian territories on the mainland. Going beyond what Contarini presented, Edward Muir (2000) offers a fascinating account of how the institutional and legal framework of the Republic reached the farthest parts of the Venetian terraferma and fostered the political education of local communities in resisting outside and often arbitrary rule, maintaining the liberty of their own little res publicae, and institutionalizing conflict into litigation through legal channels. Muir is quick to point out that "these [local] practices were not so much exported from Venice as licensed by Venice" $(2000,159)$. Villagers learned to successfully resist arbitrary local rule by invoking the protection of the written word from Venice. This suggests how shared were the mental images of the working of instrumentalities of governance, the strategic opportunities provided by those instrumentalities, and the common knowledge required to pursue contrasting community interests (see also Muir 1981; cf. cases of collective action among peasants and villagers in the Holy Roman Empire, Wilson 2016, 581-2; and compare also villagers from Spanish Lombardy appreciating the liberty in nearby Bergamo provided by the Republic of Venice in Manzoni's classic novel The Betrothed, [1827] 1909, chaps. 16 and 17).

\section{Conclusion}

In a sweeping tour of how the coercive power of the state has been historically controlled through a pluralistic distribution of political power, Scott Gordon suggests that Contarini's The Republic of Venice may be just as instructive as Machiavelli's The Prince to students of politics, if not far more so $(1999,161-2)$. For Gordon, Machiavelli's chief contribution to the modern study of politics is twofold: a secular view of the state and construing humankind as self-interested creatures. That, in Gordon's compelling view, is the extent of Machiavelli's contribution to the study 
of politics, for Machiavelli "does not examine the organization of government as a means for making collective decisions, and despite his republicanism, he does not consider how the liberty of the citizen may be preserved, or how the self-interest of the governors may be directed to the service of the general welfare" (162). Contarini, he continues, is as secular as Machiavelli and as realistic in his view of human nature, but he goes much further, "examining in detail the machinery of Venetian government and analyzing its dynamics" (162). This leads Gordon to suggest that Contarini "did for political science what Adam Smith's model of the marketplace later did for economics: it showed how a stable social order can be achieved without a hierarchical structure of authority" (162).

Suggesting that Contarini be placed alongside Machiavelli and favourably comparing Contarini with Adam Smith may be fitting for a political economist like Gordon who specializes in the history of theoretical and institutional economics; but I suspect that those who have invested much of their professional lives in the study of Renaissance political thought may not be persuaded as I am by Gordon's assessment. They may find it easier to accept the view offered by historian Frederic Lane when he noted that "compared to all other political organizations prior to the American and French revolutions, the government of ... communes [like Venice] was the one which offered [in the words of Robert Lopez] to the 'greatest number a chance to make [the] voice [of the people] heard in the conduct of public business" (1966b, 523; see also Fink 1945, 31-4). Better still, they may accept, or not object to, the assessment of S.E. Finer, who in a multivolume study of government from the earliest times advances the view that the government of Venice

was the best in the world and it would remain so till perhaps the eighteenth century ... Although the city was ruled by an aristocracy of perhaps only one fortieth of the total population, that proportion of active citizens was a far wider band of participants than was to be met with in the late feudal monarchies and principalities. $(1997,1016-17$, italics in the original)

\section{Finer continues:}

Admittedly Venice's structure was better designed than most [of the city republics] ... But if the active citizenry who manned the councils and rotated through the ever-more numerous boards and commissions had been even a fraction as contentious and violent as those in cities like Florence, the Venetian constitution would hardly have worked any better. It worked so splendidly because, in the last resort, the aristocracy that worked it - and for that matter the quasi aristocracy of cittadini originari with their names in 
their own "Silver Book" - were imbued with a sense of responsibility for the Republic that transcended their rivalries ... The rules of debate, especially in the Senate, which forbid insult and slander, reprove emotionalism and demagoguery and seek ... to keep discussion low-key, practical, and consensual, are another manifestation of their attitudes. In their great crises this Venetian aristocracy behaved like Roman senators and magistrates in their golden days, during the Hannibalic wars. They exhibited a respect for the mos maiorum, the laws of the Republic, and then exhibited what one can only call, really, a sense of state. (1018; see also conclusion in Norwich 1989)

Against this backdrop, the significance of Contarini's Republic of Venice resides in this: it shows that it is possible for fallible human beings to create and operate a complex system of accountable and productive governance over a long period of time. It equally shows that it is possible, on a smaller scale and in a more efficacious way than the Holy Roman Empire, for a polycentric system of governance in premodern times to hold violence in check, to endure as an alternative to national monarchies and unitary rule, and to represent another pathway to economic and political development. Contarini's account of the Republic of Venice broadens and enriches our understanding of the "generative capacity" (Psarra 2018) of people to devise systems of governance for themselves to the point of inspiring the search for other such experiments in world history and in our own time. 